\title{
Urinary Schistosomiasis and Asymptomatic Bacteriuria among Individuals of Ipogun, Nigeria: Detection of Predominant Microorganisms and Antibiotic Susceptibility Profile
}

\author{
Ebenezer Olayemi Dadaa and Benita Adebanke Alaghab $\square$ \\ ${ }^{a}$ Department of Microbiology, Federal University of Technology Akure, P.M.B 704 Akure, 340001,Nigeria

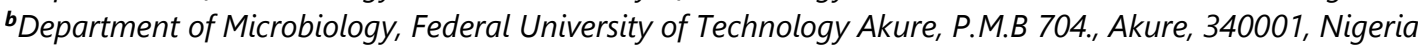

$\square$ Corresponding Author: Benita Adebanke Alagha, E-mail: benitalag@gmail.com

\section{ARTICLE INFORMATION ABSTRACT}

Received: 08 September 2021

Accepted: 04 October 2021

Published: 14 October 2021

Dol: 10.32996/jmhs.2021.2.2.8

\section{KEYWORDS}

Urinary schistosomiasis, Schistosoma haematobium, Bacteriuria, Co-infection, Ipogun
The development of bacteriuria and subsequent antibiotic resistance may be facilitated by infection with the parasite Schistosoma hematobium. This situation has been described in some African countries like Nigeria, Sudan and Congo. The present study aimed to assess the association of bacteriuria with Schistosoma haematobium infection in Ipogun, located in Ifedore Local Government, South-west, Ondo State, Nigeria. One hundred and nine (109) terminal urine samples were collected from inhabitants of the community and analyzed for the presence of bacteriuria and ova of Schistosoma haematobium via culture and microscopy respectively. Our findings revealed that 81 (74.31\%) samples had bacteriuria and 42 (38.53\%) were infected with Schistosoma haematobium. Of the 42 samples that were positive for schistosomiasis, 32 (76.19\%) were associated with bacteriuria. Gram negative bacteria associated with co-infection of urine samples with schistosomiasis demonstrated a higher level of resistance to conventional antibiotics compared to bacteria isolated from single bacteriuria infection. Findings from the study highlight the role of Schistosoma haematobium in the perpetuation of antibiotic resistance in cases of co-infection with bacteriuria.

\section{Introduction}

Urinary schistosomiasis is a urogenital disease caused by Schistosoma haematobium, a parasitic flatworm that parasitizes the venous plexus of the bladder and other urogenital organs. The name is derived from haematuria (bloody urine), which serves as the classical sign of the disease (Atalabi \& Adubi, 2018). For decades, urinary schistosomiasis has ravaged Nigerian communities, parasitizing local dwellers and inflicting severe morbidity and disabilities among affected populations (Awosolu et al., 2020). Being an infectious disease of poverty, it disproportionately afflicts poor and marginalized communities, predisposing the affected population to a greater risk of human immune virus (HIV) and cancer, prolonging the course of enterobacterial infections and eliciting antimicrobial resistance (Awosolu et al., 2020; Mohamed et al., 2019; Wall et al., 2019; Hsiao et al., 2016).

According to Hsiao et al. (2016), a symbiotic relationship exists between some bacterial strains and schistosomes which make dual infection particularly difficult to diagnose and treat. Studies in Nigeria, Sudan and the Democratic Republic of Congo have also unearthed a direct relationship between co-infection of Salmonella and either S. haematobium or S. mansoni (Ige and Agbo, 2018; Abdo et al., 2015; Mbuyi-Kalonji et al., 2020). Observations from the studies of Hsiao et al. (2016), and Barnhill et al. (2011), also revealed that adult schistosomes confer a form of protection to co-contaminant bacteria, enabling them to evade antibiotic therapy, thus prolonging their course and facilitating antibiotic resistance. Meanwhile, co-infection of urinary schistosomiasis and bacteriuria has been reported in Nigerian communities like Ibadan, Amazunge, Enugu State, Ipogun, Ogun State and Owerri, among which Staphylococcus aureus and Gram negative organisms like Esherichia coli, Klebsiella Spp, Proteus Spp, and Pseudomonas aeruginosa were implicated to be the chief causal agent of secondary urinary tract infections (UTI) among schistosomiasis infected cases (Adeyeba and Ojeaga, 2004; Ossai et al., 2012; Okechukwu et al., 2014; Amoo et al., 2017; Nwachukwu et al., 2018). Nonetheless, the problem of antibiotic resistance especially among Gram- Enterobacteriaceae family

Copyright: (c) 2021 the Author(s). This article is an open access article distributed under the terms and conditions of the Creative Commons Attribution (CC-BY) 4.0 license (https://creativecommons.org/licenses/by/4.0/). Published by Al-Kindi Centre for Research and Development, London, United Kingdom. 
remains a public health concern. Antibiotics like trimethoprim, sulfamethoxazole, and quinolone are often considered the first choice of drug for UTI worldwide. However, due to antibiotic resistance, several life-threatening side effects, repeated high doses, high cost and low efficacy of these antibiotics, it is becoming increasingly difficult to treat urinary tract infections (Saheen et al., 2019). Owing to the continuous endemicity of schistosomiasis in Ipogun (Oniya and Jeje, 2010; Oniya et al., 2013; Oboh et al., 2018) and the quick proliferation of secondary bacterial infections in cases of urinary schistosomiasis (Amoo et al., 2017; Nwachukwu et al., 2018), it is expedient to carry out new research to establish the link between these two cases, and unearth novel findings on the susceptibility patterns of associated bacteria to conventional antibiotics.

\section{Methods}

\subsection{The Study Area}

This study was carried out in Ipogun, $\left(7^{\circ} 19^{\prime} \mathrm{N} ; 5^{\circ} 05^{\prime} \mathrm{E}\right)$, a town located in Ifedore Local Government, Nigeria. The primary source of water for agricultural activities and most domestic activities is "Aponmu" river, flowing through the village. The river serves as a contact site for infection of the disease because it is home to bulinus snails that are an intermediary host for S. haematobium (Oboh et al., 2018). Furthermore, children visit the stream as a means of recreation to play and bath, women primarily visit the stream to fetch water for domestic and household use, while men being primarily farmers use the water for their farming activities. Other sources of river in the community include "Asala" river and "Odo-lona-oko" river. However, Aponmu is frequently visited by the inhabitants than the other rivers. The community was purposefully selected for this study based on previous reports on the endemicity of urinary schistosomiasis in the area.

\subsection{Ethical Consideration}

A research proposal was submitted to the State Health Research Ethics Committee, Ministry of Health, to obtain ethical approval for the conduct of the study. A preliminary visit was also paid to the King of the community for advocacy and permission to conduct the study. Assent of adults included in the study and parental consent for the inclusion of children were also obtained.

\subsection{Collection of Urine Samples}

A total of 109 clean catch, terminal urine samples were collected between 10:00am and 2:00pm. Each subject was given a sterile, screw-capped universal bottle carrying specific identification number. Information on socio-economic, demographic, risk factors and clinical presentations were collected from every participant using standardized questionnaires. In addition, they were advised to include the last few drops of the urine passed because they often contain the highest number of eggs of Schistosoma haematobium (Cheesbrough, 2006). Females were also advised to properly clean their genitals before urinating to avoid false cases of bacteriuria. Inquiry was made from female subjects to ascertain those in their monthly period; such subjects were excluded from the study to avoid false haematuria counts. Collected urine samples were immediately placed in a cold box containing ice packs and transported to the Microbiological Laboratory of the University for analyses.

\subsection{Physical Examination of Urine}

Urine samples brought to the laboratory were first examined physically for the presence of haematuria and other parameters like colour, turbidity, foam and viscosity. After which each sample was divided into two parts and labelled A and B for bacteriological and parasitological analysis respectively. Part A was subjected to bacteriological analysis immediate after physical examination while part B was placed in a black nylon and preserved in a refrigerator for parasitological analysis.

\subsection{Parasitological Examination of Urine}

Urine samples in each universal bottle was mixed thoroughly to re-suspend urine deposits after which $10 \mathrm{~mL}$ of the urine sample was transferred into a centrifuge tube using a sterile disposable $10 \mathrm{~mL}$ syringe. This was centrifuged at $1500 \mathrm{rpm}$ for $5 \mathrm{minutes}$. After decanting the supernatant, the tube was tapped gently to re-suspend the urine deposit. With a Pasteur pipette, a drop of the re-suspended deposit was transferred to a clean grease free glass slide and covered with a cover slide. The preparation was then examined under the microscope for the presence of eggs of Schistosoma hematobium using x40 objective lens with iris diaphragm sufficiently closed to get good contrast.

\subsection{Isolation and Identification of Bacteria from Urine}

Bacteria were isolated from urine samples by inoculating the urine samples in Cystine Lactose Electrolyte Deficient (CLED) agar for 24 hours at $37^{\circ} \mathrm{C}$. The preliminary identification of bacterial isolates was carried out by sub-culturing the isolates on differential and selective media (Mannitol Salt Agar (MSA), MacConkey Agar and Eosin Methylene Blue (EMB) Agar), after which biochemical identification of isolates were carried out.

\subsection{Collection of Typed Bacterial Isolates}

Typed bacteria cultures were obtained from Federal Institute of Industrial Research, Oshodi, Nigeria. The cultures were confirmed by morphological identification and biochemical tests and were maintained at $4{ }^{\circ} \mathrm{C}$ on slopes of Nutrient agar. 


\subsection{Antibiotic Assay}

The susceptibility pattern of clinical and typed bacterial isolates to conventional antibiotics was evaluated using disc diffusion assay. Gram negative disc employed in this study contained CN- Gentamycin $10 \mu \mathrm{g}$, S- Streptomycin $30 \mu \mathrm{g}$, PEF- Reflacine $10 \mu \mathrm{g}$,

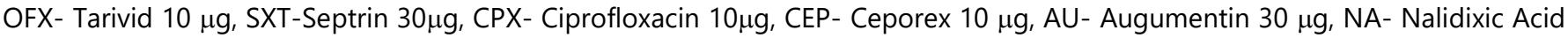
$30 \mu \mathrm{g}$, PN- Ampicilin $30 \mu \mathrm{g}$. While the Gram positive disc contained CN-Gentamycin $10 \mu \mathrm{g}$, S- Streptomycin $30 \mu \mathrm{g}$, NB-

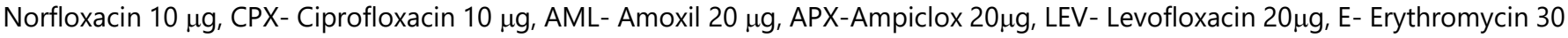

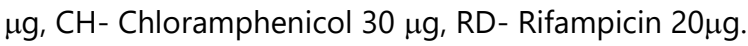

\subsection{Statistical Analysis}

Data obtained from this study were expressed as mean \pm standard deviation and were subjected to two-way analysis of variance (ANOVA) of the treatment means, showing significant difference $(P \leq 0.05)$ and were separated using Duncan's multiple range tests. Data on the prevalence of schistosomiasis and bacteriuria were analyzed with Chi square.

\section{Results}

\subsection{Prevalence of Urinary Schistosomiasis.}

Table 1 shows the prevalence of urinary schistosomiasis in relation to gender. Out of the 109 subjects examined, 42 of them were infected representing an overall prevalence of $38.53 \%$. Comparatively, females had a higher occurrence of urinary schistosomiasis (29 cases) than males (13 cases). There was a significant difference ( $P=0.00$ at $5 \%$ level of significant) in the rate of urinary schistosomiasis between the male and female genders. Table 2 shows the prevalence of urinary schistosomiasis in relation to age. Highest occurrence was observed among age group $0-10$ and 11-20 with 13 cases respectively followed by 61 above (11 cases), while the lowest occurrence was observed among the age group 51-60 (1 case). There was a significant difference ( $P=0.03$ at $5 \%$ level of significance) in the occurrence of schistosomiasis across the different age groups.

\subsection{Prevalence of Bacteriuria with Respect to Age}

Table 3 shows the prevalence of bacteriuria in relation to age. Highest occurrence was observed among age group 1-10 (24 cases), followed by 61 and above (23 cases) and 11-20 (21 cases) while the lowest occurrence was observed among the age group 51-60 (3 cases). There was no significant difference ( $P=0.48$ at $5 \%$ level of significance) in the occurrence of bacteriuria across the different age groups. Table 4 shows the prevalence of bacteriuria in relation to gender. Comparatively, females had a higher occurrence of bacteriuria (53 cases) than males (28 cases). There was no significant difference ( $P=0.10$ at $5 \%$ level of significance) in the rate of bacteriuria between the male and female genders.

\subsection{Occurrence of Bacteria Isolates in Urine Samples}

The prevalence of bacteria isolates obtained from urine samples from the study area is shown in Table 5. Eighty-nine (89) bacteria genera were encountered, of which Klebsiella pneumoniae had the highest prevalence with 23 (21.1\%), followed by Proteus vulgaris with 17 (15.60\%), Escherichia coli with 13 (11.93\%), Yersinia enterocolitica with 11 (10.1\%), Staphylococcus aureus with 10 (9.217\%), Enterobacter aerogenes with 8 (7.33\%), Salmonella enterica with 5(4.59\%) and Pseudomonas aeruginosa with 2 (1.83\%) prevalence respectively.

\subsection{Bacteriuria Associated with Urinary Schistosomiasis (Co-infection)}

Table 6 shows the cases of bacteriuria that are associated with urinary schistosomiasis. Out of 42 samples that were positive for ova of Schistosoma haematobium 32 (76.19\%) showed the presence of bacteriuria. Of the 67 urine samples that were negative to schistosomiasis, 49 (73.13\%) showed the presence of bacteriuria.

\subsection{Antibiogram Assay}

Table 7 and 8 shows the susceptibility pattern of isolated Gram-negative bacteria and their typed strains to conventional antibiotics. Gram negative bacteria isolated in co-infection of urine samples with schistosomiasis were less susceptible to antibiotics than those isolated from single bacteriuria infection. Table 9 shows the susceptibility pattern of isolated Staphylococcus aureus and typed S. aureus to conventional antibiotics. Both the clinical and typed S. aureus demonstrated a similar susceptibility pattern to conventional antibiotics. 
Table 1: Prevalence of Urinary Schistosomiasis in Relation to Age

\begin{tabular}{|c|c|c|c|c|c|}
\hline \multirow[b]{2}{*}{$\begin{array}{l}\text { Age group } \\
\text { (Years) }\end{array}$} & \multicolumn{5}{|c|}{ No examined } \\
\hline & $\begin{array}{c}\text { Infected } \\
\text { (Prevalence \%) }\end{array}$ & Not infected & Total & Chi-square value & Degree of freedom \\
\hline $01-10$ & 13 (11.93\%) & 17 & 30 & 5.485 & 6 \\
\hline $11-20$ & 13 (11.93 \%) & 14 & 27 & & \\
\hline $21-30$ & 0 (0 \%) & 0 & 0 & & \\
\hline $31-40$ & $0(0 \%)$ & 6 & 6 & & \\
\hline $41-50$ & $4(3.67 \%)$ & 6 & 10 & & \\
\hline $51-60$ & 1 (0.92 \%) & 2 & 3 & & \\
\hline $61>$ & 11 (10.09\%) & 22 & 33 & & \\
\hline Total & $42(38.53 \%)$ & 67 & 109 & & \\
\hline
\end{tabular}

Table 2: Prevalence of Urinary schistosomiasis in Relation to Gender

\begin{tabular}{|c|c|c|c|c|c|}
\hline \multirow[b]{2}{*}{ Sex } & \multicolumn{5}{|c|}{ No examined } \\
\hline & $\begin{array}{c}\text { Infected } \\
\text { (Prevalence \%) }\end{array}$ & Not infected & Total & Chi-square value & Degree of freedom \\
\hline Male & $\begin{array}{c}13 \\
(11.93 \%)\end{array}$ & 22 & 35 & 2.887 & 1 \\
\hline Female & $\begin{array}{c}29 \\
(26.61 \%)\end{array}$ & 45 & 74 & & \\
\hline Total & $\begin{array}{c}42 \\
(38.53 \%)\end{array}$ & 67 & 109 & & \\
\hline
\end{tabular}


Table 3: Prevalence of Bacteriuria with Respect to Age

\begin{tabular}{|c|c|c|c|c|c|}
\hline \multirow[b]{2}{*}{$\begin{array}{l}\text { Age group } \\
\text { (Years) }\end{array}$} & \multicolumn{5}{|c|}{ No examined } \\
\hline & $\begin{array}{c}\text { Infected } \\
\text { (Prevalence \%) }\end{array}$ & Not infected & Total & Chi-square value & Degree of freedom \\
\hline $01-10$ & 24 (22.01\%) & 6 & 30 & 14.161 & 6 \\
\hline $11-20$ & 21 (19.27\%) & 6 & 27 & & \\
\hline $21-30$ & $0(0 \%)$ & 0 & 0 & & \\
\hline $31-40$ & $4(3.67 \%)$ & 2 & 6 & & \\
\hline $41-50$ & $6(5.50 \%)$ & 4 & 10 & & \\
\hline $51-60$ & $3(2.75 \%)$ & 0 & 3 & & \\
\hline $61>$ & 23 (21.1\%) & 10 & 33 & & \\
\hline Total & 81 (74.31\%) & 28 & 109 & & \\
\hline
\end{tabular}

Table 4: Prevalence of Bacteriuria with Respect to Gender

\begin{tabular}{|c|c|c|c|c|c|}
\hline \multirow{2}{*}{ Sex } & \multicolumn{5}{|c|}{ No examined } \\
\hline & $\begin{array}{c}\text { Infected } \\
\text { (Prevalence \%) }\end{array}$ & Not infected & Total & $\begin{array}{l}\text { Chi-square } \\
\text { value }\end{array}$ & Degree of freedom \\
\hline Male & $\begin{array}{c}28 \\
(25.69 \%)\end{array}$ & 7 & 35 & 13.219 & 1 \\
\hline Female & $\begin{array}{c}53 \\
(48.62 \%)\end{array}$ & 21 & 74 & & \\
\hline Total & $\begin{array}{c}81 \\
(74.31 \%)\end{array}$ & 67 & 109 & & \\
\hline
\end{tabular}


Table 5: Prevalence of Bacterial Isolates in the Urine Samples

$$
N=109
$$

\begin{tabular}{lcc}
\hline \multicolumn{1}{c}{ Isolates } & Number of occurrence & Prevalence (\%) \\
\hline Klebsiella pneumonia & 23 & 21.1 \\
Proteus vulgaris & 17 & 15.60 \\
Escherichia coli & 13 & 11.93 \\
Yersinia enterocolitica & 11 & 10.1 \\
Staphylococcus aureus & 10 & 9.17 \\
Enterobacter aerogenes & 8 & 7.33 \\
Salmonella enterica & 5 & 4.59 \\
Pseudomonas aeruginosa & 2 & 81.65 \\
Total & 89 & KEY.
\end{tabular}

$\mathrm{N}=$ Total Number of Urine Samples Analyzed

Table 6: Bacteriuria Associated with Urinary Schistosomiasis (Co-infection)

\begin{tabular}{|c|c|c|c|}
\hline & $\begin{array}{c}\text { Urinary Schistosomiasis Cases } \\
\text { Number (Prevalence \%) }\end{array}$ & $\begin{array}{c}\text { Non Urinary Schistosomiasis Cases } \\
\text { Number (Prevalence \%) }\end{array}$ & $\begin{array}{c}\text { Total } \\
\text { Number } \\
\text { (Prevalence \%) }\end{array}$ \\
\hline Presence of bacteriuria & 32 (39.5\%) & 49 (60.5\%) & $81(74.31 \%)$ \\
\hline Absence of bacteriuria & 10 (35.7\%) & 18 (64.29\%) & 28 (25.69\%) \\
\hline Total & 42 (38.5\%) & 67 (61.5\%) & 109 (100\%) \\
\hline
\end{tabular}


Table 7: Antibiotic Susceptibility Pattern of Gram-Negative Isolates to Conventional Antibiotics

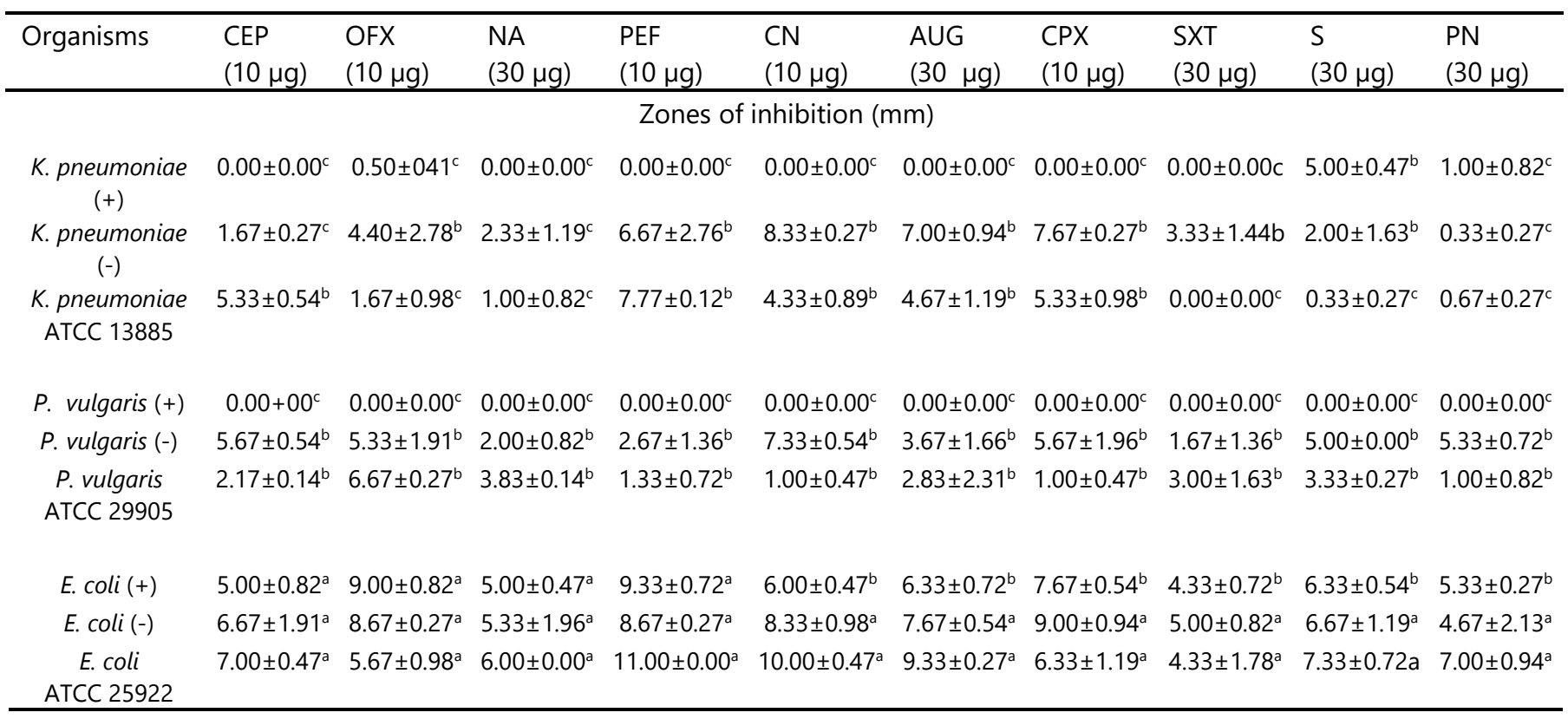

Values represent mean \pm standard error of triplicate readings. Values with the same letters down the same column are not significantly different at $p$-value $\leq 0.05$ (ANOVA and DMRT).

KEY: (+): Bacteria in co-infection of urine samples with schistosomiasis;

(-): Bacteria in single bacteriuria infection of urine sample

Table 8: Antibiotic Susceptibility Pattern of Gram-Negative Isolates to Conventional Antibiotics

\begin{tabular}{|c|c|c|c|c|c|c|c|c|c|c|}
\hline Organisms & $\begin{array}{c}\text { CEP } \\
(10 \mu g)\end{array}$ & $\begin{array}{c}\text { OFX } \\
(10 \mu g)\end{array}$ & $\begin{array}{c}\text { NA } \\
(30 \mu g)\end{array}$ & $\begin{array}{c}\text { PEF } \\
(10 \mu g)\end{array}$ & $\begin{array}{c}\text { CN } \\
(10 \mu g)\end{array}$ & $\begin{array}{c}\text { AUG } \\
(30 \mu g)\end{array}$ & $\begin{array}{c}\text { CPX } \\
(10 \mu g)\end{array}$ & $\begin{array}{c}\text { SXT } \\
(30 \mu g)\end{array}$ & $\begin{array}{c}S \\
(30 \mu g)\end{array}$ & $\begin{array}{c}\text { PN } \\
(30 \mu g)\end{array}$ \\
\hline \multicolumn{11}{|c|}{ Zones of inhibition (mm) } \\
\hline E. aerogenes $(+)$ & $0.00 \pm 0.00^{c}$ & $\begin{array}{c}1.33 \pm 0.2 \\
7^{c}\end{array}$ & $0.00 \pm 0.00^{c}$ & $0.00 \pm 0.00^{c}$ & $0.00 \pm 0.00^{c}$ & $0.00 \pm 0.00^{c}$ & $1.00 \pm 0.47^{c}$ & $0.00 \pm 0.00^{c}$ & $0.00 \pm 0.00^{c}$ & $0.00 \pm 0.00^{c}$ \\
\hline E. aerogenes (-) & $4.17 \pm 0.49^{b}$ & $\begin{array}{c}8.67 \pm 0.7 \\
2^{b}\end{array}$ & $4.00 \pm 0.47^{b}$ & $8.33 \pm 0.98^{b}$ & $7.00 \pm 1.41^{b}$ & $6.33 \pm 0.27^{b}$ & $7.33 \pm 0.72^{b}$ & $3.00 \pm 0.47^{b}$ & $5.67 \pm 0.27^{b}$ & $6.00 \pm 0.47^{b}$ \\
\hline E. aerogenes & $7.00 \pm 0.00^{\mathrm{a}}$ & $9.00 \pm 0.0$ & $8.00 \pm 0.24^{a}$ & $9.00 \pm 0.47^{a}$ & $9.50 \pm 0.24^{\mathrm{a}}$ & $9.00 \pm 0.47^{a}$ & $9.00 \pm 0.00^{\mathrm{a}}$ & $5.33 \pm 2.18^{a}$ & $5.00 \pm 2.05^{a}$ & $9.17 \pm 0.14^{\mathrm{a}}$ \\
\hline ATCC 29905 & & $0^{\mathrm{a}}$ & & & & & & & & \\
\hline $\begin{array}{l}\text { Salmonella } \\
\text { enterica }(+)\end{array}$ & $5.67 \pm 1.44^{b}$ & $\begin{array}{c}7.00 \pm 0.9 \\
4^{b}\end{array}$ & $4.33 \pm 0.27^{b}$ & $7.00 \pm 1.25^{b}$ & $5.67 \pm 0.27^{b}$ & $6.33 \pm 0.72^{b}$ & $7.33 \pm 0.72^{b}$ & $6.00 \pm 1.89^{b}$ & $7.00 \pm 0.82^{b}$ & $3.67 \pm 1.66^{b}$ \\
\hline $\begin{array}{l}\text { Salmonella } \\
\text { enterica. (-) }\end{array}$ & $3.33 \pm 1.36^{b}$ & $\begin{array}{c}8.00 \pm 0.8 \\
2^{b}\end{array}$ & $4.33 \pm 2.42^{b}$ & $7.33 \pm 0.54^{b}$ & $3.33 \pm 1.44^{b}$ & $6.00 \pm 0.94^{b}$ & $5.67 \pm 1.91^{\mathrm{b}}$ & $1.33 \pm 1.09^{b}$ & $5.33 \pm 0.54^{b}$ & $3.33 \pm 1.44^{b}$ \\
\hline $\begin{array}{l}\text { S. typhii ATCC } \\
14028\end{array}$ & $8.50 \pm 0.85^{a}$ & $\begin{array}{c}9.33 \pm 0.2 \\
7^{a}\end{array}$ & $9.33 \pm 0.27^{\mathrm{a}}$ & $9.33 \pm 0.27^{a}$ & $9.33 \pm 0.27^{\mathrm{a}}$ & $9.33 \pm 0.27^{\mathrm{a}}$ & $9.33 \pm 0.27^{\mathrm{a}}$ & $7.17 \pm 0.14^{\mathrm{a}}$ & $9.00 \pm 0.47^{\mathrm{a}}$ & $9.67 \pm 0.27^{a}$ \\
\hline $\begin{array}{c}Y \text {. enterocolitica } \\
(+)\end{array}$ & $5.33 \pm 0.72^{b}$ & $\begin{array}{c}5.33 \pm 0.5 \\
4^{b}\end{array}$ & $6.67 \pm 1.96^{b}$ & $\begin{array}{c}10.67 \pm 0.27 \\
a\end{array}$ & $4.67 \pm 1.19^{b}$ & $4.67 \pm 0.98^{b}$ & $5.00 \pm 0.94^{b}$ & $3.33 \pm 0.72^{b}$ & $6.33 \pm 0.27^{b}$ & $4.00 \pm 1.70^{b}$ \\
\hline $\begin{array}{c}Y . \text { enterocolitica } \\
(-)\end{array}$ & $\begin{array}{c}10.67 \pm 0.27 \\
\mathrm{a}\end{array}$ & $\begin{array}{c}10.67 \pm 0 \\
27^{\mathrm{a}}\end{array}$ & $\begin{array}{c}10.67 \pm 0.27 \\
a\end{array}$ & $\begin{array}{c}10.67 \pm 0.27 \\
a\end{array}$ & $\begin{array}{c}10.67 \pm 0.27 \\
a\end{array}$ & $\begin{array}{c}10.67 \pm 0.27 \\
a\end{array}$ & $\begin{array}{c}10.67 \pm 0.27 \\
a\end{array}$ & $\begin{array}{c}10.67 \pm 0.27 \\
a\end{array}$ & $\begin{array}{c}10.67 \pm 0.27 \\
a\end{array}$ & $10.67 \pm 0.27^{a}$ \\
\hline
\end{tabular}

Values represent means \pm standard error of triplicate readings. Values with the same letters down the same column are not significantly different at $p$-value $\leq 0.05$ (ANOVA and DMRT).

KEY: (+): Bacteria in co-infection of urine samples with schistosomiasis;

(-): Bacteria in single bacteriuria infection of urine samples 
JMHS 2(2): 70-80

Table 9: Antibiotic Susceptibility Pattern of Gram-Positive Isolates to Conventional Antibiotics

\begin{tabular}{|c|c|c|c|c|c|c|c|c|c|c|}
\hline Organisms & $\begin{array}{l}\text { RD } \\
(20 \mu g)\end{array}$ & $\begin{array}{l}\text { AML } \\
(20 \mu \mathrm{g})\end{array}$ & $\begin{array}{l}S \\
(30 \mu g)\end{array}$ & $\begin{array}{l}\text { NB } \\
(10 \mu g)\end{array}$ & $\begin{array}{l}\mathrm{CH} \\
(30 \mu g)\end{array}$ & $\begin{array}{l}\text { CPX } \\
(10 \mu g)\end{array}$ & $\begin{array}{l}E \\
(30 \mu g)\end{array}$ & $\begin{array}{l}\text { LEV } \\
(20 \mu g)\end{array}$ & $\begin{array}{l}\text { CN } \\
(10 \mu g)\end{array}$ & $\begin{array}{l}\text { APX } \\
(20 \mu g)\end{array}$ \\
\hline \multicolumn{11}{|c|}{ Zones of Inhibition (mm) } \\
\hline S. aureus (+) & $9.33 \pm 0.27^{b}$ & $9.33 \pm 0.27^{b}$ & $9.33 \pm 0.27^{b}$ & $9.33 \pm 0.27^{b}$ & $5.33 \pm 0.27^{b}$ & $5.33 \pm 0.27^{b}$ & $9.00 \pm 0.00^{b}$ & $8.67 \pm 0.27^{b}$ & $5.00 \pm 0.47^{b}$ & $3.00 \pm 0.47^{b}$ \\
\hline S. aureus (-) & $10.33 \pm 0.27^{a}$ & $9.67 \pm 0.54^{a}$ & $9.67 \pm 0.54^{a}$ & $6.33 \pm 0.72^{a}$ & $9.00 \pm 0.47^{a}$ & $10.17 \pm 0.36^{a}$ & $9.67 \pm 0.27^{a}$ & $8.67 \pm 0.54^{a}$ & $8.50 \pm 0.62^{a}$ & $9.33 \pm 0.27^{a}$ \\
\hline $\begin{array}{l}\text { S. aureus } \\
\text { (NCTC 6571) }\end{array}$ & $10.33 \pm 0.27^{a}$ & $9.67 \pm 0.54^{a}$ & $9.67 \pm 0.54^{a}$ & $6.33 \pm 0.72^{a}$ & $9.00 \pm 0.47^{a}$ & $10.17 \pm 0.36^{a}$ & $9.67 \pm 0.27^{a}$ & $8.67 \pm 0.54^{a}$ & $8.50 \pm 0.62^{a}$ & $9.33 \pm 0.27^{a}$ \\
\hline
\end{tabular}

Values represent means \pm standard error of triplicate readings. Values with the same letters down the same column are not significantly different at $p$-value $\leq 0.05$ (ANOVA and DMRT)

KEY: $\quad(+)$ : Bacteria in co-infection of urine samples with schistosomiasis;

(-): Bacteria in single bacteriuria infection of urine samples

\section{Discussion}

In some Nigerian studies, the presence of Schistosoma haematobium infection was reported to be significant in the development of bacteriuria (Anosike et al., 2001; Adeyeba and Ojeaga, 2004; Nwachukwu et al., 2018). Also, interaction between the genus Schistosoma and Gram-negative bacteria has been putatively reported to result in lingering bacterial infection and failure in antibiotic treatment (Barnhill et al., 2011). Hence, this study assessed the relationship between bacteriuria and urinary schistosomiasis in a Schistosoma haematobium endemic community in a rural area in South west Nigeria.

The overall prevalence of urinary schistosomiasis observed in this study affirms that the study area is endemic for urinary schistosomiasis because $38.5 \%$ is above the maximum prevalence limit of $25 \%$ as recommended by World Health Organization (WHO, 1991), which clearly reveals that urinary schistosomiasis is still a major public health problem in the study area. The notably high prevalence of bacteriuria also uncovers the silently deteriorating health status of the community members which is ostensibly unnoticed as there is a dearth of information on the prevalence of single bacteriuria infection and co-infection of bacteriuria and schistosomiasis in the area. Majority of scholarly articles on the study area are concentrated on Schistosomiasis, except the study of Dada (2015), on co-infection of bacteria associated with schistosomiasis and only among school aged students in the area.

The observed prevalence (35.8\%) of Schistosomiasis is similar to the prevalence rates of 38\% reported by Dada (2015), in Ipogun and 39\% reported by Ossai et al. (2012), in Enugu. Although their studies focused solely on school aged students in their respective study area while ours was focused on the entire age groups. The steady persistence of urinary schistosomiasis in the study area despite the annual mass administration of praziquantel as recommended by W.H.O was found to be associated with the continued dependence of the community members on river Aponmu as a source of water supply as there are no pipe borne water in the community. It has been previously reported that the river serves as a source of transmission of the infective stage of the parasite (Oboh et al., 2018). The general unavailability of good sanitary facilities also contributes to the persistence of the disease. Majority of the participants indicated that they do not have flushable toilet facilities in their homes or schools (for pupils) and resort to nearby bushes, latrines and the river for defecation and urination - all of which can contribute immensely to the transmission of urinary schistosomiasis in the area.

Schistosoma haematobium prevalence in this study had significant association with age group and gender. Being a holoendemic disease, it is mostly common among children within the age bracket of 1-15 years of age (Atalabi \& Adubi, 2018). This could be because children are important risk population that are continually exposed to the parasite via frequent stream visit, mostly for recreational purposes like swimming and domestic purposes like fetching water. The higher prevalence of urinary schistosomiasis among females may be attributed to their engagement in domestication and need to visit the stream to fetch water for cooking, 
cleaning and washing. The higher prevalence of schistosomiasis in females in this study could also be because more females volunteered to participate in the study which could have introduced bias in the sampling.

There are no previous records on the prevalence of bacteriuria in the study area; however the high prevalence of bacteriuria observed in this study is similar to the findings of Mwabete and Msigwa (2017) and Ndako et al. (2019), who recorded high prevalence of bacteriuria in rural communities in Tanzania and Nigeria respectively. The high prevalence may be due to low standards of living, social habits of the community, poor sanitation and unhygienic behavioural tendencies which particularly predispose individuals in rural settings to urinary tract infections (Ndako et al., 2019).

The highest prevalence of bacteriuria observed among children is similar to the findings of Onifade et al. (2011). A number of host factors predispose children to UTI; these include obstructive uropathy, urolithiasis, incomplete emptying of the bladder with residual urine, non-circumcision in boys, female sex after infancy, and constipation (Adeseye \& Ezeaka, 2018). Furthermore, the high prevalence of bacteriuria in females corresponds with previous studies on bacteriuria where females were reported to have higher carriage of bacteriuria than males (Ndako et al., 2019; Onifade et al., 2011). This could be as a result of the anatomically short urethra among female, favouring bacterial accent into the bladder. The predominance of Gram negative bacteria in this study coincides with the findings of Mwabete and Msigwa (2017) and Singh et al. (2014), in rural communities where Gram-negative bacterial isolates occurred the most in both asymptomatic bacteriuria and symptomatic UTI. This may be attributed to the presence of fimbriae which enables them to successfully colonize the urinary tract.

Statistical analysis of the obtained data depicted that schistosomiasis was not significant for bacteriuria (at $P=0.4$ ), which annuls the theory that a causal connection exists between schistosomiasis and bacterial UTI. Nonetheless, the fact that a lower level of antibiotic efficacy was observed against some bacteria population isolated from subjects with co-infection of bacteriuria and schistosomiasis compared to isolates from subjects with single bacteriuria infection, further lend credence to the possibility that adult schistosomes confer protection to co-contaminant bacteria in dual infection. Previous studies revealed that this protection is due to the ability of bacteria to bind with the tegument of adult schistosomes via fimbrial protein present on the surface of some Gram negative bacteria (Barnhill et al., 2011). Thus, the presence of fimbrial proteins in Gram negative uropathogens might have aided Gram negative bacteria implicated in co-infection in this study to form a niche with Schistosoma haematobium, hence, becoming less susceptible to antibiotics. In addition to these, bacteriuria carriage was slightly higher among schistosomiasis infected subjects than non-infected subjects (76.19\% versus $73.13 \%)$. It has been reported that lack of proper treatment of asymptomatic bacteriuria can increase the chances of developing into acute cyctitis and pyelonephritis by 15-45\% (Vasudevan, 2014). Therefore, the extent of antibiotic resistance demonstrated by Gram negative bacteria isolated from co-infection of urine samples in this study is an issue of concern. Given the high prevalence of bacteriuria in the study area and the resistance of associated bacteria to conventional antibiotics, the study highlighted the health implications of association of bacteriuria in urinary schistosomiasis in the study area.

\subsection{Conclusion}

Poor sanitation and use of untreated water are important root cause of urinary tract infection among residents of rural communities. These factors also contribute immensely to the transmission of urinary schistosomiasis and the consolidation of coinfection of bacterial UTI and urinary schistosomiasis in endemic communities. From the present findings, it can be concluded that the association between bacteria and urinary schistosomiasis could be deleterious, resulting to failure in the treatment of bacteriuria, thereby posing a greater risk of eventual development into symptomatic and complicated UTI. As such, the government should provide potable water and adequate sanitary facilities to community to improve sanitation and reduce transmission of the disease. Water bodies should also be treated with molluscacide to eliminate bulinus snails required to maintain the life cycle of $S$. haematobium in the study area. Additionally, improved sanitation health education and appropriate case management should be incorporated to improve the health of individuals in endemic areas. Since literature reveals that Gram-negative bacteria associated with Schistosomiasis can evade antibiotics by binding to the teguments of the adult worms, it is therefore recommended that invitro molecular studies should be carried out on antibiotic resistant bacteria associated with Schistosomiasis to expound the mechanism of resistance in the absence of adult schistosomes. Furthermore, the antibacterial potency of medicinal plants against associated bacteria should be investigated.

\section{Declarations}

\section{Ethics approval and consent to participate}

The study was approved by Ondo State Health Research Ethics Committee (OSHREC) with Ethical Protocol number OSHREC/03/02/20/266. Duly signed informed consents were obtained from subjects to express their voluntary interest to participate in the study after properly explaining the purpose and scope of the research in English language (or Yoruba language for non-English speakers. 
Consent for publication: Not applicable.

Availability of data and material: The authors confirm that the data supporting the findings of this study are available within the article and it's supporting attached files.

Competing interests: No potential conflict of interest was reported by the authors.

Funding: This research did not receive any specific grant from funding agencies in the public, commercial, or not-for-profit sectors.

Authors' contributions: Author EOD designed the study; BAA managed the literature searches, conducted the experiment, and performed the statistical analysis, wrote the protocol and wrote the first draft of the manuscript. Author EOD reviewed the manuscript and BAA managed the analyses of the study. Both authors read and approved the final manuscript. All the authors have accepted responsibility for the entire content of this submitted manuscript and approved submission.

Acknowledgements: Not applicable

List of Abbreviations

UTI - Urinary Tract Infection

\section{References}

[1] Abdo, K. S., Bilal, N. E., and Ibrahim, M. E. (2015). Frequent Carriage of Invasive Salmonella amongst Patients Infected with Schistosomiasis in Sudan. African Journal of Microbiology Research. 9(8), 543-548.

[2] Adeseye, M. A. and Ezeaka, C. (2018). Prevalence and risk factors of Asymptomatic Bacteriuria among Children Living with HIV in Lagos, Nigeria. The Pan African Medical Journal - ISSN 1937-8688. Pages 1-6.

[3] Adeyeba, O. A. and Ojeaga, S. G. T. (2004). Urinary Schistosomiasis and Concontaminat Urinary Tract Pathogens among School Children in Metropolitan Inadab, Nigeria. African Journalm of Biomedical Research. 5, 103-107.

[4] Amoo, K. J., Amoo, A. J. K., Oke, A. A. and Adegboyega, T. T. (2017). Prevalence of Urinary Tract Infection (UTI) and Concomitant Urinary Schistosomiasis among Primary School Children in Remo North Local Government, Ogun State, Nigeria. Journal of Dental and Medical Sciences. 16(11), 68-73.

[5] Anosike, J. C., Nwoke, B. E. B., Okere, A. N., Alozie, J. I., Okoro, U. O., Nwosu, D. C., Ogbulie, J. N. and Amadi, A. N. C. (2001). Endemicity of Urinary Schistosomiasis in North central zone of Abia State, Nigeria. International Journal for Environmental Health and Human Development. 2(2), 5-12.

[6] Atalabi, T. E. and Adubi, T. O. (2018). The Epidemiology and Chemotherapeutic Approaches to the Control of Urinary Schistosomiasis in School-Age Children (SAC): A Systematic Review. BMC Infectious Diseases. 19,73.

[7] Awosolu, O. B., Shariman, Y. Z., Haziqah, M. T. F. and Olusi, T. A. (2020). Will Nigerians Win the War against Urinary Schistosomiasis? Prevalence, Intensity, Risk factors and Knowledge Assessment among South-western Nigeria. Pathogens. 9(2), 128. Doi: 10.3390/pathogens.9020128. PMID: 32079189.

[8] Barnhill, A. E., Novozhilova, E., Day, T. A. and Carlson, S. A. (2011). Schistosoma-associated Salmonella Resist Antibiotics via Specific Fimbrial Attachments to the Flatworm. Parasites and Vectors. 4, 123-129.

[9] Cheesbrough, M. (2006). District Laboratory Practice in Tropical Countries. Part 2, $2^{\text {nd }}$ Edition, Cambridge University Press, New York. Page 62.

[10] Dada, E. O. (2015). Urinary Schistosomiasis associated with bacteriuria among school aged pupils in Ipogun Ondo State, Nigeria. International Journal of Pure \& Applied Bioscience. 3(6), 59-64.

[11] Hsiao, A., Toy, T., Seo, H. J. and Marks, F. (2016). Interaction between Salmonella and Schistosomiasis: A Review. Plos Pathogens. 12(12), E1005928

[12] Igwe, N. N., and Agbo, E. A. (2014). "Incidence of co-infection of enteric Salmonella with Schistosoma in Kachia Local Government Area of Kaduna State, Nigeria". International Journal of Tropical Medicine and Public Health. 3(1), 12-17

[13] Mbuyi-Kalonji, L., Barbe, B., Nkoji, G., Madinga, J., Roucher, C., Linsuke, S., Marie, H., Anne-Sophie, H., Wesley, M., Katja, P., Pascal, L., MarieFrance, P., Octavie, L. and Jan, J. (2020). Non-Typhoidal Salmonella Intestinal Carriage in a Schistosoma Mansoni Endemic Community in a Rural Area of the Democratic Republic of Congo. Plos Neglected Tropical Diseases. 14(2), E0007875

[14] Mohamed, J., Ayun, C., Thierno, D., Omar, G., Medina, N., Mouhamadou, M. M., Mahamat, A. M., Abdourahmane, D., Cherif, D., Issa, L., Lamine, N. and Serigne, M. G. (2019). Is Schistosomiasis a Risk Factor for Bladder Cancer? Evidence-Based Facts. Journal of Tropical Medicine. Volume 2020, Article ID 8270810. 6 Pages.

[15] Mwabete, K. D. and Msigwa, O. G. (2017). Prevalence of Asymptomatic Urinary Tract Infection among Pregnant Women in Rural and Urban area in Tanzania. East and Central African Journal of Pharmaceutical Sciences. 20, 27-32.

[16] Ndako, J. A., Solomon, O., Owolabi, A., Fajobi, V., Okolie, C., Akinwunmi, J. and Phiobor, G. O. (2019). Incidence of Urinary Tract Infection in a Rural Community of South-west, Nigeria. Saudi Journal of Biomedical Research. ISSN 2518-3222. Pages 306-311.

[17] Nwachukwu, I. O., Ukaga, C. N., Ajero, C. M. U., Nwoke, B. E. B., Nwachukwu, M. I., Obasi, C. C. and Ezenwa, C. M. (2018). "Urinary Schistosomiasis and concomitant bacteriuria in the school age children in some parts of Owerri, Imo State," International Research Journal of Advanced Engineering and Science. 3(1), 107-115.

[18] Oboh, M. A., Idowu, E. T., Mafe, M. A. and Otunbnanjo, O. A. (2018). Persistency of Schistosomiasis Infection among School Age Children in Ipogun Area of Ondo State Nigeria. EC Microbiology. 14(7), $400-407$. 
[19] Okechukwu, P. O., Raymond, D., Chimezie, N., Dahiru, T., Peter, N., Daniel, O., Osaeloka, E., Godwin, A., Echezona, E., Patrick, N., Douglas, N., Suleiman, I. and George, E. (2014). Bacteriuria and Urinary Schistosomiasis in Primary School Children in Rural Communities in Enugu State, Nigeria, 2012. The Pan African Medical Journal. 18(1), 15. https://doi.org/10.11604/pamj.supp.2014.18.1.4169

[20] Oniya, M. O. and Jeje, O. (2010). Urinary Schistosomiasis: Efficacy of Praziquantel and Association of the ABO blood grouping in Disease Epidemiology. International Journal for Biotechnology and Molecular Biology Research. 1(3), 31-35.

[21] Oniya, M. O., Ishola, M. A. and Jayeoba, O. D. (2013). Schistosomiasis in Ipogun: Update Assessment on Endemicity and Efficacy of Praziquantel in Chemotherapy. International Journal of Tropical Disease and Health. 3(1), 37-44.

[22] Onifade, A. K., Anibijuwon, I. I. and Azariah, E. J. (2011). Urinary Tract Infection in Apparently Healthy Individuals in Ile-ife, Nigeria: Detection of Predominant Microorganisms and Antibiotics Susceptibility Profile. African Journal of Microbiology Research. 5(20), 3233-3236.

[23] Ossai, O. P., Dankoli, R., Nwodo, C., Tukur, D., Nsubuga, P., Ogbuabor, D., Ekwueme, O., Abonyi, G., Ezeanolue, E. and Eze, G. (2014). Bacteriuria and Urinary Schistosomiasis in Primary School Children in Rural Communities in Enugu State, Nigeria, 2012. Pan African Medical Journal. 18(1), 15.

[24] Saheen, G., Shah, S. M. A., Akram, M. and Munir, N. (2019). Therapeutic Potential of Medicinal Plants for the Management of Urinary Tract Infection: A Systematic Review. Clinical Experimental Pharmacology and Physiology. 10, 1440-1681.

[25] Singh, B., Tilak, R., Srivasta, R. K. and Katiyar, D. (2014). Urinary Tract Infection and its Risk Factors in Women: An Appraisal. Journal of Pure and Applied Microbiology. 8(5), 504-514.

[26] Vasudevan, R. (2014). Urinary Tract Infection: an Overview of the Infection and the Associated Risk Factors. Journal of Microbiology and Experimentation. 1(2), 42-54.

[27] Wall, K. M., Kilembe, W., Vwalika, B., Dinh, C., Livingston, P., Lee, Y., Lakhi, S., Boeras, D., Naw, H., Brill, I., Chomba, E., Sharkey, T., Parker, R., Shutes, E., Tichacek, A., Secor, W. E. and Allen, S. (2019). Schistosomiasis is associated with Incident HIV Transmission and Death in Zambia. PLos Neglected Tropical Disease. 12(12), PMC6292564.

[28] World Health Organization (1991). Second Report of the WHO Expert Committee on the Control of Schistsosmiasis. Genera, Switzerland. 